\title{
Sentiment Analysis of Twitter in Tourism Destinations
}

\section{Carmen Pérez Cabañero, Enrique Bigné, Carla Ruiz, Antonio Carlos Cuenca}

Department of Marketing, University of Valencia, Spain.

\begin{abstract}
Given the importance of electronic word of mouth (eWOM), this paper analyses the content of messages generated by users related to a tourist destination and shared through Twitter. We propose three research questions regarding eWOM behaviour in Twitter focused on the expertise of the reviewer, sentiment analysis of a tweet and its content. In order to address those research questions we carry out text mining analysis by retrieving existing information on Twitter (over 1500 tweets) regarding to Venice as a tourist destination.
\end{abstract}

Keywords: Twitter; eWOM; tourism, sentiment analysis. 


\section{Introduction}

Social media have deeply changed the way users search tourism information and share their travel experience, emotions and experiential moments. Electronic word of mouth (eWOM) refers to "any statement made by potential, actual or former consumers about a product, service or company, which is available to a multitude of people and institutions via Internet" (Hennig-Thurau et al., 2004). Despite tremendous attention to eWOM in tourism research, destinations have attracted only 10\% of the papers published from 2009 to 2016 in major tourism and hospitality journals (Sotiriadis, 2017).

\section{Goals}

This paper analyses the content of messages generated by users (User Generated Content, UGC) related to a tourist destination and shared through Twitter. More specifically we focus on the sentiment of tweets. Sentiment analysis refers to the subjective value of the content of the online comments which is typically expressed as positive or negative (Alaei, Becken and Stantic, 2019).

Yoo and Gretzel (2011) have found that United States travelers as creators of UGC are mostly motivated by altruistic and hedonic benefits. In contrast, self-centred motivations include possibilities for gaining recognition, increasing social ties and augmenting one's self-esteem, among others (Gretzel and Yoo, 2008). Based on self-centered motivations the end goal of a tweet is to be influential. Research on the influence or centrality has recently emerged through different measures (see for a review Riquelme and González-Cantergiani, 2016). We wonder whether experienced users post more positive or negative comments. Therefore we posit the following research question: RQ1. Does the expertise of the reviewer influence on the sentiment of his/her tweets?.

Stieglitz and Dag-Xuan (2013) argue that the expression of emotions in social media-based textual content may also lead to more attention and arousal, which in turn may positively affect information sharing behaviour. According to their empirical results, twitter messages that feature a high degree of emotionality tend to trigger more retweets. In order to confirm this outcome, we propose: RQ2. Does the sentiment of a tweet impact on eWOM behaviour in Twitter?

Previous research suggests that there is only a small percentage of tweets that participants retweet. Tweets containing links are rated as being significantly more interesting than tweets without links, but hashtags make no difference in terms of perceived interest (Counts and Fisher, 2011). We wonder about the impact of several components of the tweet on eWOM behavior. Therefore, we propose the following research question: RQ3. Which of the 
information cues of a tweet (images, links, hashtags, bookmarks) can best predict eWOM behavior in Twitter?

\section{Methodology}

We carry out text mining analysis by retrieving existing information on Twitter (over 14,000 tweets) regarding Venice as a tourist destination. The selection of the comments under analysis is based on the mention ten selected keywords for analysis: Tourism, holiday in Venice, travel Venice, getaway to Venice, booking Venice, Venice port, weather in Venice, venice hotels, flights to Venice and, to see in Venice. We asses expertise of a Twitter user derived from the number of years using Twitter, number of tweets made, and number of subscribed lists. eWOM behaviour is measured based on the number of retweets, the user's reachness and the tweet's effective reachness. Sentiment analysis was made using Meaning Cloud. We obtained an ordinal variable for classifying the content of the tweets from 1 very negative to 5 very positive. Statistical analysis was carried out using IBM SPSS 26.

\section{Results}

The sample is made up of 14,338 tweets collected during July and August of 2016. There are 6,352 original tweets, 311 are responses and 7,675 are retweets. Regarding the demographics of users, 4,500 were posted by women and 2,082 men, all of them are originally posted in English but the origin and the age of users is unknown.

Regarding the first research question relating the expertise of the user and the sentiment of tweets, we will select only original tweets (reponses and retweets will not be considered). A regression analysis reveals the different impact of the number of years using Twitter, the number of tweets made and the number of lists subscribed (see table1).

Table 1. Regression analysis on Sentiment.

\begin{tabular}{lrrrrrr}
\hline & $\begin{array}{c}\text { Unstand. } \\
\text { Beta }\end{array}$ & \multicolumn{1}{c}{$\begin{array}{c}\text { St.coef. } \\
\text { Beta }\end{array}$} & \multicolumn{1}{c}{ t } & Sig & Tolerance & FIV \\
\hline Constant & 4.187 & & 169.653 & $0.000^{* * *}$ & & \\
Years & -0.054 & -0.152 & -8.783 & $0.000^{* * *}$ & 0.970 & 1.031 \\
Number of lists & $2.767 \mathrm{E}-6$ & 0.110 & 5.938 & $0.000^{* * *}$ & 0.838 & 1.193 \\
$\begin{array}{l}\text { Number of } \\
\text { tweets }\end{array}$ & $-4.791 \mathrm{E}-7$ & -0.065 & -3.444 & $0.001^{* * *}$ & 0.815 & 1.226 \\
& & & & & & \\
\hline
\end{tabular}

$\mathrm{R}=0.190 ; \mathrm{R} 2=0.036 ; \mathrm{F}=41.440(\mathrm{Sig}=0.000) ;$ Durbin-Watson= 1.605; $* * *=\mathrm{p}<0.01$

Dependent variable: Sentiment 
Therefore, the more years the user is using Twitter, the more negative the messages. This variable is the most influential of the analysis (its standadrdized Beta of -0.152 is the highest). Addtionally, the more lists the user is susbscribed, the more positive the tweets of that user. This positive relationship is illustrated by the standadrdized Beta of 0.110 . Finally, the users with a lot of tweets posted have a tendency to post negative ones as shown by its standadrdized Beta of -0.065 which is quite low but significant.

Regarding the second research question about the impact of the sentiment of tweets on eWOM, we carried out a ANOVA with the subsample of the original tweets. The variable sentiment is the factor in our analysis. We considered several aspects of eWOM such as the number of retweets achieved, the user's reachness and the tweet's effective reachness. User's reachness is measured adding the user's followers plus the followers of those retweeting and those answering the tweet. The tweet's effective reachness is measured adding the number of answers, the number of tweets with mentions and the number of retweets. The data offered heterocedascidity of variances so we report the Welch statistic as a Robust test of equality of means and the Games-Howell post hoc analysis. These results are shown in Table 2 though we only show the cells with significant relationships.

In order to understand the results obtained out of the comparison of means above, we include the Table 3 which contains the main descirptives of this analysis.

The results in Table 2 show that the are different means for the number of retweets reached between neutral and positive reviews. According to results in Table 3, Neutral tweets only make an average of 0.24 retweets while Positive tweets make an average of 2.57 retweets. In general terms, the more positive the tweet the higher the number of retweets it achieves. There are also different means for the user's reachness regarding Very negative and Positive tweets. According to Table 3, Very negative tweets achieve an average of 2,259.72 followers while Positive tweets achieve an average of 19,787.69 followers. Thus, the reachness of Very negative tweets is the least of all tweets. With respect to the effective reachness of the tweets, there are statistical differences between the mean of Very negative tweets and the means of Negative, Positive and Very positive tweets. According to Table 3, the mean of Very negative tweets is 718.35 , which is the lowest score in that calculation. Concluding this analysis, we can state that Very negative and negative tweets have less impact on eWOM behavior. 
Table 2: Welch statistics and Games-Howell post hoc analysis.

\begin{tabular}{|c|c|c|c|c|c|}
\hline $\begin{array}{c}\text { Dependent } \\
\text { variable }\end{array}$ & & & $\begin{array}{c}\text { Mean } \\
\text { difference }\end{array}$ & Std. error & Sig. \\
\hline \multirow{4}{*}{$\begin{array}{l}\text { Number of } \\
\text { retweets }\end{array}$} & \multirow[t]{4}{*}{3 Neutral } & 1 Very negative & -0.0008 & 0.180 & 1.000 \\
\hline & & 2 Negative & -1.722 & 0.958 & 0.377 \\
\hline & & 4 Positive & -2.332 & 0.852 & $0.049 *$ \\
\hline & & 5 Very positive & -157.247 & 141.224 & 0.799 \\
\hline \multirow{4}{*}{$\begin{array}{l}\text { User's } \\
\text { reachness }\end{array}$} & \multirow{4}{*}{$\begin{array}{l}1 \text { Very } \\
\text { negative }\end{array}$} & 2 Negative & -40441.541 & 30111.98 & 0.664 \\
\hline & & 3 Neutral & -2982.310 & 1902.231 & 0.521 \\
\hline & & 4 Positive & -17527.97 & 3151.534 & $0.000 * * *$ \\
\hline & & 5 Very positive & -61102.612 & 29754.87 & 0.242 \\
\hline \multirow{4}{*}{$\begin{array}{l}\text { Tweet's } \\
\text { effective } \\
\text { reachness }\end{array}$} & \multirow{4}{*}{$\begin{array}{l}1 \text { Very } \\
\text { Negative }\end{array}$} & 2 Negative & -4940.020 & 1790.307 & $0.048^{*}$ \\
\hline & & 3 Neutral & -1914.375 & 1557.351 & 0.734 \\
\hline & & 4 Positive & -6071.102 & 1021.187 & $0.000 * * *$ \\
\hline & & 5 Very positive & -5878.971 & 1307.420 & $0.000 * * *$ \\
\hline
\end{tabular}
$* * *=\mathrm{p}<0.001 ; *=\mathrm{p}<0.05$

Number of retweets: Welch statistic $=2.962 ; \mathrm{df} 1=4 ; \mathrm{df} 2=322.452 ; \mathrm{Sig} .=0.020$

User's reachness: Welch statistic $=9.341 ; \mathrm{df} 1=4 ; \mathrm{df} 2=619.169 ;$ Sig. $=0.000$

Tweet's effective reachness: Welch statistic $=12.846 ; \mathrm{df} 1=4 ; \mathrm{df} 2=483.425 ;$ Sig. $=0.000$ 
Table 3. Descriptives.

\begin{tabular}{|c|c|c|c|c|}
\hline & & $\mathbf{N}$ & Mean & Std. Deviation \\
\hline \multirow{5}{*}{$\begin{array}{l}\text { Number of } \\
\text { retweets }\end{array}$} & 1 Very negative & 37 & 0.243 & 1.011 \\
\hline & 2 Negative & 347 & 1.965 & 17.811 \\
\hline & 3 Neutral & 99 & 0.242 & 0.701 \\
\hline & 4 Positive & 1997 & 2.574 & 37.945 \\
\hline & 5 Very positive & 869 & 157.490 & 4163.130 \\
\hline \multirow[t]{5}{*}{ User's reachness } & 1 Very negative & 37 & 2259.729 & 5041.584 \\
\hline & 2 Negative & 347 & 42701.270 & 560711.589 \\
\hline & 3 Neutral & 99 & 5242.040 & 17035.862 \\
\hline & 4 Positive & 1997 & 19787.699 & 135877.437 \\
\hline & 5 Very positive & 869 & 63362.341 & 876797.807 \\
\hline Tweet's effective & 1 Very negative & 37 & 718.351 & 2804.553 \\
\hline \multirow[t]{4}{*}{ reachness } & 2 Negative & 347 & 5658.371 & 32224.824 \\
\hline & 3 Neutral & 99 & 2632.727 & 14800.793 \\
\hline & 4 Positive & 1997 & 6789.453 & 40718.484 \\
\hline & 5 Very positive & 869 & 6597.322 & 36065.084 \\
\hline
\end{tabular}

Finally we examine the information cues of a tweet (images, mentions, and hashtags) which impact on eWOM behavior in Twitter. These information cues are nominal variables (whether it is included or not in the tweet) so we produce several t-test where the dependent variable refers to eWOM behavior, that is the number or retweets, the user's reachness and the tweet's effective reachness. As eWOM behavior is under study, we select original tweets in our sample. The descriptives about the tweets containing hashtags, mentions and images are shown in next Table 4. 
Table 4. Descriptives according to cues.

\begin{tabular}{|c|c|c|c|c|}
\hline & Hashtag & $\mathbf{N}$ & Mean & Std. deviation \\
\hline \multirow[t]{2}{*}{ Number of retweets } & No & 2818 & 46.45 & 2301.98 \\
\hline & Yes & 3534 & 4.40 & 195.51 \\
\hline \multirow[t]{2}{*}{ User's reachness } & No & 2818 & 32636.43 & 540239.86 \\
\hline & Yes & 3534 & 26616.84 & 178098.94 \\
\hline \multirow[t]{3}{*}{ Tweet's eff. reachness } & No & 2818 & 6218.54 & 144704.06 \\
\hline & Yes & 3534 & 15209.52 & 57711.21 \\
\hline & Mention & $\mathbf{N}$ & Mean & Std. deviation \\
\hline \multirow[t]{2}{*}{ Number of retweets } & No & 5613 & 22.81 & 1630.93 \\
\hline & Yes & 739 & 24.93 & 432.14 \\
\hline \multirow[t]{2}{*}{ User's reachness } & No & 5613 & 24198.18 & 379868.61 \\
\hline & Yes & 739 & 67941.79 & 408622.99 \\
\hline \multirow[t]{3}{*}{ Tweet's eff. reachness } & No & 5613 & 11234.27 & 111014.91 \\
\hline & Yes & 739 & 11118.18 & 48214.26 \\
\hline & Picture & $\mathbf{N}$ & Mean & Std. deviation \\
\hline \multirow[t]{2}{*}{ Number of retweets } & No & 406 & 15.14 & 91.74 \\
\hline & Yes & 5946 & 23.60 & 1591.71 \\
\hline \multirow[t]{2}{*}{ User's reachness } & No & 406 & 37267.21 & 256520.91 \\
\hline & Yes & 5946 & 28742.50 & 390727.29 \\
\hline \multirow[t]{2}{*}{ Tweet's eff. reachness } & No & 406 & 257.55 & 1561.60 \\
\hline & Yes & 5946 & 11969.35 & 109149.54 \\
\hline
\end{tabular}

The results regarding the t-test analyses are shown in the Table 5 below. Firstly, the assumption of equal variances is checked by means of the F statistic. Thus, in case the significance associated to the $\mathrm{F}$ statistic is higher than 0.05 we report the corresponding $\mathrm{t}$ statistic when equal variances are assumed. Alternatively, in case the significance associated to the $\mathrm{F}$ statistic is lower than 0.05 we report the corresponding $\mathrm{t}$ statistic when equal variances are not assumed. 
Table 5. Results of t-test analyses.

\begin{tabular}{|c|c|c|c|c|c|c|}
\hline & Hashtag & $\mathbf{F}$ & Sig. & $\mathbf{t}$ & df & Sig. \\
\hline $\begin{array}{l}\text { Number of } \\
\text { retweets }\end{array}$ & $\begin{array}{l}\text { Equal variances } \\
\text { not assumed }\end{array}$ & 4.612 & $0.032 *$ & 0.967 & 2849.42 & 0.334 \\
\hline $\begin{array}{l}\text { User's } \\
\text { reachness }\end{array}$ & $\begin{array}{l}\text { Equal variances } \\
\text { assumed }\end{array}$ & 3.498 & 0.061 & 0.621 & 6350 & 0.534 \\
\hline \multirow[t]{2}{*}{$\begin{array}{l}\text { Tweet's eff. } \\
\text { reachness }\end{array}$} & $\begin{array}{l}\text { Equal variances } \\
\text { not assumed }\end{array}$ & 27.472 & $0.000 * * *$ & -3.107 & 3531.59 & $0.002 * *$ \\
\hline & Mention & $\mathbf{F}$ & Sig. & $\mathbf{t}$ & df & Sig. \\
\hline $\begin{array}{l}\text { Number of } \\
\text { retweets }\end{array}$ & $\begin{array}{l}\text { Equal variances } \\
\text { assumed }\end{array}$ & 0.001 & 0.973 & -0.035 & 6350 & 0.972 \\
\hline $\begin{array}{l}\text { User's } \\
\text { reachness }\end{array}$ & $\begin{array}{l}\text { Equal variances } \\
\text { not assumed }\end{array}$ & 22.022 & $0.000 * * *$ & -2.757 & 913.93 & $0.006 * *$ \\
\hline \multirow[t]{2}{*}{$\begin{array}{l}\text { Tweet's eff. } \\
\text { reachness }\end{array}$} & $\begin{array}{l}\text { Equal variances } \\
\text { assumed }\end{array}$ & 0.100 & 0.752 & 0.028 & 6350 & 0.978 \\
\hline & Picture & $\mathbf{F}$ & Sig. & $\mathbf{t}$ & df & Sig. \\
\hline $\begin{array}{l}\text { Number of } \\
\text { retweets }\end{array}$ & $\begin{array}{l}\text { Equal variances } \\
\text { assumed }\end{array}$ & 0.049 & 0.825 & -0.107 & 6350 & 0.915 \\
\hline $\begin{array}{l}\text { User's } \\
\text { reachness }\end{array}$ & $\begin{array}{l}\text { Equal variances } \\
\text { assumed }\end{array}$ & 0.973 & 0.324 & 0.433 & 6350 & 0.665 \\
\hline $\begin{array}{l}\text { Tweet's eff. } \\
\text { reachness }\end{array}$ & $\begin{array}{l}\text { Equal variances } \\
\text { not assumed }\end{array}$ & 14.943 & $0.000 * * *$ & -8.262 & 5979.90 & $0.000 * * *$ \\
\hline
\end{tabular}

The results in Table 4 and 5 show the influence that several cues included in the tweets have on eWOM behavior. Thus, we can conclude that tweets having hashtags have a higher effective reachness $(\mathrm{t}=-3.107$, sig. $=0.002)$. Tweets having mentions of other Twitter users increase user's reachness $(\mathrm{t}=-2.757$, sig. $=0.006)$. Finally, tweets having pictures increase their effective reachness $(\mathrm{t}=-8.262$, sig. $=0.000)$.

In conclusion, this paper analysed the content of a collection of tweets related to Venice as a tourist destination and applied sentiment analysis. Several aspects related to the user's expertise impact on the sentiment of tweets posted like the number of years the user is in Twitter and the tweets posted overall. Sentiment of tweets also impact on eWOM behaviour. 
The more positive the tweet the higher the number of retweets it achieves while negative tweets have less impact on eWOM behavior. Regarding the content analysis of the tweet, having hashtags and pictures impact on the tweet's effective reachness while having mentions impact on the user's reachness. Management destination organisations could benefit from current results to make a higher impact of their tweets, for example including hashtags and pictures to improve the tweet's effective reachness and including mentions to gather potential new followers. Further research can enlarge the sample of tweets under study and compare different tourist attractions like free attractions (for instance a park, a main square or a cathedral) and paid-for attractions (like museums, castles and private buildings).

\section{Acknowledgements}

Authors acknowledge financial support of research project UV-INV_AE19-1212255.

\section{References}

Alaei, A. R., Becken, S., \& Stantic, B. (2019). Sentiment analysis in tourism: capitalizing on big data. Journal of Travel Research, 58(2), 175-191.

Counts, S., \& Fisher, K. (2011). Taking It All In? Visual Attention in Microblog Consumption. ICWSM, 11, 97-104.

Gretzel, U., \& Yoo, K. H. (2008). Use and impact of online travel reviews. Information and communication technologies in tourism 2008, 35-46.

Hennig-Thurau T., Gwinner K., Walsh G., \& Gremler d. (2004). Electronic Word-of-Moud Vía Consumer-Opinion Platforms: What Motivates Consumer to Articulate Themselves on the internet. Journal of Interactive Marketing, 18(1), 38-52.

Riquelme, F., \& González-Cantergiani, P. (2016). Measuring user influence on Twitter: A survey. Information Processing \& Management, 52(5), 949-975.

Sotiriadis, M. D. (2017). Sharing tourism experiences in social media. International Journal of Contemporary Hospitality Management, 29(1), 179-225.

Stieglitz, S., \& Dang-Xuan, L. (2013). Emotions and information diffusion in social mediasentiment of microblogs and sharing behavior. Journal of management information systems, 29(4), 217-248.

Yoo, K. H., \& Gretzel, U. (2011). Influence of personality on travel-related consumergenerated media creation. Computers in Human Behavior, 27(2), 609-621. 